\title{
Deskripsi Pemecahan Masalah Matematika pada Materi Sistem Persamaan Linear Dua Variabel Siswa Kelas VIII SMP Negeri Polewali Mandar
}

\author{
Amran Yahya \\ Pendidikan Matematika, Fakultas Keguruan dan Ilmu Pendidikan, Universitas Sulawesi Barat \\ amranyahya@unsulbar.ac.id
}

\begin{abstract}
Abstrak
Penelitian ini merupakan penelitian deskriptif. Tujuan penelitian ini adalah Bagaimana Kemampuan Siswa dalam memecahkan masalah matematika pada materi sistem persamaan linier dua variabel (SPLDV) siswa kelas VIII SMP Negeri Polewali Mandar. Dari perolehan tersebut yang menunjukkan deskripsi dalam pemecahan masalah pada siswa kelas VIII SMP Negeri Polewali Mandar. Pada materi sistem persamaan linier dua variabel yaitu 6 siswa (18\%) berada pada kategori sangat tinggi dan sebanyak 12 siswa (36\%) berada pada kategori tinggi, 13 siswa (40\%) berada pada kategori sedang dan 2 siswa (6\%) berada pada kategori rendah dan tidak ada siswa yang berada pada kategori sangat rendah. Untuk skor rata-rata yang diperoleh adalah 78,72 dari skor maksimum 90 dengan standar deviasi 8,36 dan variansi sebesar 70,01.
\end{abstract}

Kata Kunci: Pemecahan Masalah, Sistem Persamaan Linear Dua Variable.

\section{Pendahuluan}

Pendidikan sebagai bagian penting dalam kehidupan manusia memiliki tujuan untuk meningkatkan potensi peserta didik agar dapat menjadi pribadi yang terampil, kreatif, mandiri, berakhlak mulia, serta bertakwa kepada Tuhan Yang Maha Esa. Dalam Pendidikan mencakup berbagai macam bidang ilmu salah satunya adalah matematika. Matematika sebagai salah satu cabang ilmu penting dalam Pendidikan memegang peranan dalam pengembangan berbagai disiplin ilmu, seperti ilmu fisika, kimia, biologi, komputer dan lain-lain. Dalam sistem Pendidikan Indonesia matematika merupakan salah satu pelajaran yang diujikan dalam ujian nasional, sehingga sangat penting untuk dipelajari dan dipahami. Tetapi ironisnya, matematika selalu dianggap sebagai momok menakutkan bagi siswa, mereka berpendapat bahwa matematika itu sulit dan membosankan.

Pembelajaran matematika yang bersifat monoton menjadikan guru sebagai pusat yang lebih aktif berceramah dibandingkan dengan aktivitas siswa, serta pemberian tugas yang juga kurang variatif cenderung mengakibatkan kurang memberi kesempatan kepada siswa dalam mengembangkan dan menemukan pemahamannya sendiri, sehingga belajar matematika menjadi tidak bermakna. Akibatnya, informasi-informasi yang disajikan sulit diserap, diproses dan disimpan dengan baik oleh sistem memori siswa atau yang lebih sering disebut lupa. Menurut pandangan para ahli psikologi kognitif, materi pelajaran yang terlupakan oleh siswa tidak benar-benar hilang dari ingatan akalnya, materi pelajaran itu masih terdapat dalam subsistem akal permanen siswa namun terlalu lemah untuk diingat kembali sehingga diperlukan sebuah alat (pendekatan belajar) yang dapat membuat sistem memori siswa berfungsi optimal dalam memproses materi pelajaran yang diberikan (Syah, 2010). 
Pemecahan masalah merupakan salah satu kompetensi yang akan dicapai peserta didik dalam pembelajaran matematika selain kompetensi pemahaman konsep dan komunikasi pada tingkat Sekolah Menengah Pertama. Pemecahan masalah perlu diintegrasikan dalam pembelajaran matematika karena dengan mempelajari pemecahan masalah siswa diharapkan terampil dalam berpikir dan bernalar sehingga dalam proses pembelajaran siswa tidak hanya mengandalkan kemampuan hafalan saja. Silver (dalam Ikram, 2012) menjelaskan cara menilai pemecahan masalah dengan menunjukkan hubungan pemecahan masalah. Dikatakan bahwa hubungan pemecahan masalah tidak pada pengajuan masalah sendiri tetapi lebih besar pada saling pengaruh antara pemecahan masalah dan pengajuan masalah. Proses dan produk kegiatan ini dapat menentukan sebuah tingkatan pemecahan masalah dengan jelas. Selain itu, menurut Conney dalam Herman Hudojo (2005) menyatakan bahwa mengajar siswa untuk menyelesaikan masalah-masalah memungkinkan siswa itu lebih analitik di dalam mengambil keputusan di dalam kehidupan. Abdurrahman (2003) mendefinisikan pemecahan masalah sebagai aplikasi dari konsep dan keterampilan. Menurut Bayer Sebagaimana dikutip oleh Zakaria, pemecahan masalah adalah mencari jawaban atau penyelesaian sesuatu yang menyulitkan.

Berdasarkan pendapat para ahli tersebut, jelas bahwa pemecahan masalah matematika merupakan kompetensi yang ditunjukkan siswa untuk menemukan solusi atau cara yang tepat dari suatu permasalahan matematika dengan mengaplikasikan berbagai konsep dan keterampilan yang telah dimiliki. Dalam pembelajaran matematika, permasalahan yang biasa dipecahkan meliputi bidang geometri, pengukuran, aljabar, bilangan aritmatika maupun statistika. Soal-soal pemecahan masalah matematika biasanya berbentuk soal cerita yang membutuhkan langkah-langkah penyelesaian secara sistematis dan terperinci.

Jika ditinjau dari segi materi khususnya untuk melihat pemecahan masalah siswa dalam memecahkan dan mengajukan masalah khususnya pada siswa kelas VIII secara umum, materi yang dipandang memiliki banyak masalah adalah materi yang berkaitan dengan membuat model matematika dan menyelesaikan soal cerita yang berkaitan dengan system persamaan linear dua variabel. Berdasarkan hasil wawancara dengan beberapa siswa dan alumni SMP Negeri Polewali Mandar mengungkapkan bahwa materi yang dipandang sulit pada kelas VIII adalah membuat model matematika dan menyelesaikan soal cerita yang berkaitan dengan persamaan liner dua variabel. Ungkapan diatas diperkuat oleh hasil observasi awal penulis mengenai materi membuat model matematika dan menyelesaikan soal cerita yang berkaitan dengan persamaan liner dua variabel. Penulis memberikan soal kepada beberapa siswa SMP kelas VIII $\mathrm{A}_{\mathrm{A}}$ sebagai berikut: seorang petani mempunyai sebidang tanah berbentuk persegi panjang. Lebar tanah tersebut $6 \mathrm{~m}$ lebih pendek daripada panjangnya. Jika keliling tanah $60 \mathrm{~m}$ tentukan luas tanah petani tersebut! Ketika diberikan waktu beberapa menit untuk menyelesaiakan soal itu, hal yang terlihat ketika siswa akan menyelesaikan soal itu adalah: siswa tidak dapat memahami bagaimana menyelesaikan soal yang diberikan, siswa terlihat sibuk mencari rumus apa yang sesuai untuk menyelesaiakan soal itu, siswa mencari contoh-contoh soal sebelumnya yang sesuai dengan model soal yang diberikan. Setelah diberikan waktu untuk menyelesaikan soal tersebut, kebanyakan yang tidak dapat menyelesaikan soal dan bertanya "bagaimana menyelesaikan soal ini?".

Setelah diidentifikasi, peneliti menyimpulkan bahwa siswa yang bertanya tidak memperlihatkan suatu pemecahan masalah dalam menyelesaikan soal tersebut. Hal tersebut mengindikasikan bahwa siswa dalam memecahkan masalah masih rendah dan hampir setiap soal dikatakan sulit. Materi membuat model matematika dan menyelesaikan soal cerita yang berkaitan dengan persamaan liner dua variabel merupakan salah satu materi pembelajaran yang membutuhkan pemecahan masalah dan kemampuan menyelesaikan permasalahan yang berkaitan dengan konsep. 
Permasalahan itu yang berkaitan dengan konsep-konsep lain dalam matematika maupun yang berkaitan dengan pelajaran lain dalam kehidupan sehari-sehari. Pada pembelajaran persamaan linier dua variabel, masih banyak siswa yang cenderung belajar dengan cara menghafal informasi dan rumusrumus yang berkaitan dengan persamaan linier dua variabel. Sehingga siswa mengalami kesulitan untuk mengembangkan ide-ide baru dan mencari tahu cara-cara baru dalam menyelesaikan suatu permasalahan. Terlebih lagi ketika siswa diminta menyelesaikan beberapa soal pengembangan yang model dan bentuknya tidak seperti contoh soal yang diberikan pada saat guru menerangkan materi tersebut.

Berdasarkan uraian diatas, dengan melihat penelitian-penelitian terdahulu serta kajian-kajian dan fakta-fakta yang terjadi di Sekolah maka penulis bermaksud untuk mendeskripsikan secara mendetail tentang bagaimana pemecahan masalah siswa pada materi Persamaan liner dua variabel.

\section{Metode}

Jenis Penelitian

Jenis penelitian ini adalah penelitian deskriptif. Menurut Arikunto (2010: 3) "Penelitian Deskriptif adalah penelitian yang dimaksudkan untuk menyelidiki keadaan, kondisi atau hal-hal lain yang sudah disebutkan, yang hasilnya dipaparkan dalam bentuk laporan penelitian. Peneliti tidak mengubah, menambah, atau mengadakan manipulasi terhadap objek atau wilayah penelitian. Peneliti hanya memotret apa yang terjadi pada diri objek atau wilayah yang diteliti, kemudian memaparkan apa yang terjadi dalam bentuk laporan penelitian secara lugas, seperti apa adanya."

Penelitian ini bersifat menggambarkan sebagaimana dalam pemecahan masalah yang diperoleh siswa pada materi Sistem Persamaan Linier Dua Variabel (SPLDV), dimana penelitian deskriptif adalah penelitian yang menggambarkan atau melukiskan keadaan subjek maupun objek penelitian pada saat sekarang berdasarkan fakta-fakta yang nampak sebagaimana adanya, yang meliputi datadata dengan analisis data tersebut.

Subjek Penelitian

Penelitian ini dilaksanakan di SMP Negeri Polewali Mandar dimana subjek penelitian adalah Siswa kelas VIII 1 SMP Negeri Polewali Mandar. Langkah-langkah pengambilan subjek peneltian adalah:

1. Menetapkan kelas penelitian yaitu siswa kelas VIII yang telah mempelajari Sistem Persamaan Linier Dua Variabel (SPLDV). Dipilihnya kelas VIII dengan pertimbangan:

a. Siswa kelas VIII telah mengikuti serangkaian materi Sistem Persamaan Linier Dua Variabel (SPLDV yang telah diberikan guru di sekolah.

b. Karakter siswa kelas VIII relatif dikenal baik oleh guru dan tidak menggangu persiapan Ujian Nasional.

c. Kegiatan siswa kelas VIII tidak terlalu padat sehingga memudahkan siswa untuk tes.

Prosedur Penelitian

Penelitian ini dilakukan dengan prosedur sebagai berikut:

1. Kegiatan awal

a. Merancang instrumen penelitian 
Sebagai alat pengumpul data, peneliti merancang instrumen penelitian berupa naskah yang terdiri dari soal Sistem Persamaan Linier Dua Variabel (SPLDV).

b. Observasi ke lokasi penelitian

Observasi lokasi penelitian untuk memperoleh informasi dari pihak SMP Negeri Polewali Mandar mengenai izin penelitian, jadwal belajar dan waktu pelaksanaan penelitian.

2. Kegiatan inti

Pemberian tes dilaksanakan dalam waktu 80 menit dan dikerjakan oleh siswa secara serempak. Untuk mendapatkan data yang objektif dan menghindari kecurangan, maka tes dilaksanakan dengan pengawasaan yang ketat.

3. Kegiatan akhir (penyusunan laporan penelitian)

Setelah melakukan penelitian, data yang diperoleh dianalisis dengan teknik analisis yang digunakan, kemudian melakukan pembahasan dan menarik kesimpulan.

Fokus Penelitian

Untuk mengetahui bagaimana Pemecahan Masalah Sistem Persamaan Linier Dua Variabel (SPLDV) Siswa kelas VIII SMP Negeri Polewali Mandar maka yang menjadi fokus penilitian ini adalah:

1. Memberikan contoh dan non contoh dari Sistem Persamaan Linier Dua Variabel (SPLDV).

2. Menyajikan Sistem Persamaan Linier Dua Variabel (SPLDV dalam berbagai bentuk representasi matematis.

3. Menggunakan, memanfaatkan dan memilih prosedur atau operasi tertentu Sistem Persamaan Linier Dua Variabel (SPLDV).

4. Mengaplikasikan Sistem Persamaan Linier Dua Variabel (SPLDV) ke pemecahan masalah.

Instrumen

Instrumen penelitian adalah peneliti sendiri. Dalam hal ini peneliti merupakan perencana, pelaksana pengumpul data, penganalisis, penafsiran data, dan menjadi pelapor hasil penelitian. Tes pemilihan subjek penelitian memuat soal tentang Pemecahan Masalah Sistem Persamaan Linier Dua Variabel (SPLDV adalah sebagai berikut: Bagaimanakah pemecahan masalah tentang materi Sistem Persamaan Linier Dua Variabel (SPLDV) Pada Siswa Kelas VIII SMP Negeri Polewali Mandar?

\section{Definisi Operasional Variabel}

Dalam penelitian ini terdapat satu jenis variabel yaitu deskripsi pencapian tingkat pemecahan masalah Sistem Persamaan Linier Dua Variabel (SPLDV pada siswa kelas VIII SMP Negeri Polewali Mandar. Adapun definisi operasional adalah deskripsi pencapaian tingkat Pemecahan Masalah Sistem Persamaan Linier Dua Variabel (SPLDV) pada siswa kelas VIII SMP Negeri Polewali Mandar.

\section{Teknik Analisis Data}

Data yang terkumpul dari penelitian semuanya diolah atau dianalisis dengan menggunakan analisis statiktif deskriptif. Teknik analisis deskriptif dimaksudkan untuk mendeskripsikan karakteristik variabel penelitian dengan menggunakan skor tertinggi, skor terendah, rata-rata, standar deviasi, variansi dan tabel frekuensi persentase. 
Dalam penelitian ini, kriteria yang digunakan untuk menentukan pencapaian tingkat penguasaan Pemecahan Masalah siswa materi Sistem Persamaan Linier Dua Variabel (SPLDV) yaitu dengan menggunakan skala lima kategori sebagai berikut:

Tabel 1. Distribusi Hasil Tes Belajar

\begin{tabular}{lcc}
\hline Tingkat penguasaan & skor & kategori hasil belajar \\
\hline $0 \%-54 \%$ & $0-54$ & Sangat rendah \\
$55 \%-64 \%$ & $55-64$ & Rendah \\
$65 \%-79 \%$ & $65-79$ & Sedang \\
$80 \%-89 \%$ & $80-89$ & Tinggi \\
$90 \%-100 \%$ & $90-100$ & Sangat tinggi \\
\hline
\end{tabular}

Sumber: Nurkancana (1986:80)

\section{Hasil}

Hasil penelitian

Hasil penelitian tentang deskripsi Pemecahan Masalah Sistem Persamaan Linier Dua Variabel (SPLDV) pada siswa kelas VIII SMP Negeri Polewali Mandar dengan deskripsi kuantitatif. Hasil ini diperoleh siswa setelah mengerjakan tes berupa soal materi pokok tentang Sistem Persamaan Linier Dua Variabel (SPLDV). Analisis statistik ini dimaksud untuk mendeskripsikan pemecahan masalah matematika tersebut pada materi Sistem Persamaan Linier Dua Variabel (SPLDV).

Hasil Tes Pemecahan Masalah Siswa SMP Negeri Polewali Mandar Pada Materi Sistem Persamaan Linier Dua Variabel (SPLDV)

Hasil yang diperoleh dari 5 item yang dikembangkan untuk mengetahui hasil belajar matematika siswa kelas VIII SMP Negeri Polewali Mandar pada materi Sistem Persamaan Linier Dua Variabel (SPLDV) yaitu dimana nilai perolehan siswa yang sangat tinggi yang tercapai siswa yaitu skor $90-100 \%$ yang dicapai oleh 6 siswa, sedangkan nilai yang sangat terendah yaitu skor $0-54 \%$ dimana tidak siswa dalam kategori sangat rendah.

Tabel 2: Deskripsi Pemecahan Masalah Matematika Siswa Kelas VIII SMP Negeri Polewali Mandar pada materi Sistem Persamaan Linier Dua Variabel (SPLDV)

\begin{tabular}{lc}
\hline Statistik & Nilai Statistik \\
\hline Ukuran Sampel & 33 \\
Skor ideal & 100 \\
Skor maksimum & 90 \\
Skor minimum & 60 \\
Rentang Skor & 30 \\
Skor rata-rata & 78,27 \\
Median & 80,00 \\
Modus & 80 \\
Standar deviasi & 8,37 \\
Variansi & 70,01 \\
Jumlah skor & 2583 \\
\hline
\end{tabular}

Sumber: Hasil Analisis data Primer 
Tabel 2. diatas menunjukkan bahwa dari 33 sampel penelitian yang dilakukan ternyata siswa tersebut mempunyai skor rata-rata kemampuan memahami dan menyelesaikan soal matematika (materi Sistem Persamaan Linier Dua Variabel (SPLDV)) dengan memiliki standar deviasi 80,36 dan variansi 70,01 dimana skor terendah 60 dan skor tertinggi 90 dari skor ideal 100. Untuk lebih jelasnya jika kita kelompokkan ke dalam pengkategorian sebagai berikut:

Tabel 3: Frekuensi, Presentase, Skor dan Kategori Pemecahan Masalah Matematika Siswa Kelas VIII SMP Negeri Polewali Mandar pada materi Sistem Persamaan Linier Dua Variabel (SPLDV)

\begin{tabular}{lccc}
\hline Nilai & kategori & Frekuensi & Presentase (\%) \\
\hline $0-54$ & Sangat rendah & 0 & 0 \\
$55-64$ & Rendah & 2 & 6 \\
$65-79$ & Sedang & 13 & 40 \\
$80-89$ & Tinggi & 12 & 36 \\
$90-100$ & Sangat tinggi & 6 & 18 \\
\hline
\end{tabular}

Sumber: Hasil Analisis data Primer

Dari tabel 3 memberikan gambaran bahwa dalam pemecahan masalah matematika siswa kelas VIII SMP Negeri Polewali Mandar pada materi Sistem Persamaan Linier Dua Variabel (SPLDV) menyajikan nilai-nilai siswa setelah menyelesaikan soal-soal bentuk aljabar. Tabel tersebut menunjukkan bahwa sebanyak 6 siswa (18\%) berada pada kategori sangat tinggi dan sebanyak 12 siswa (36\%) berada pada kategori tinggi, 13 siswa (40\%) berada pada kategori sedang dan 2 siswa (6\%) berada pada kategori rendah dan tidak ada siswa yang berada pada kategori sangat rendah.

Berdasarkan tabel 3. maka dapat ditentukan jumlah dan presentase siswa yang memperoleh nilai 75 keatas dan siswa yang memperoleh nilai kurang dari 75 kebawah. Untuk lebih jelasnya dapat dilihat dari tabel berikut:

Tabel 4: Frekuensi dan Presentase Siswa yang Memperoleh Nilai 75 keatas dan Siswa yang Memperoleh Nilai Kurang dari 75.

\begin{tabular}{ccc}
\hline Nilai & Frekuensi & Presentase \\
\hline Nilai 75 Keatas & 26 & 79 \\
Nilai 75 Kebawah & 7 & 21 \\
\hline
\end{tabular}

Tabel 4 menujukkan bahwa jumlah dan presentase siswa yang memperoleh nilai 75 keatas dan siswa yang memperoleh nilai kurang dari 75 setelah menyelesaikan soal materi Sistem Persamaan Linier Dua Variabel (SPLDV). Dari 33 siswa, ternyata siswa yang memperoleh nilai 75 ke atas yaitu sebanyak 26 siswa (79\%) sedangkan siswa yang nilai kurang dari 75 yaitu sebanyak 7 siswa (21\%).

Pembahasan

Terlebih dahulu dijelaskan bahwa kriteria atau standar penelitian yang digunakan adalah kriteria ketuntasan minimal (KKM) mata pelajaran matematika, apabila tingkat presentase siswa mencapai $75 \%$ keatas dari jumlah siswa, maka tergolong tuntas tentang materi sistem persamaan linier dua variabel (SPLDV).

Berdasarkan hasil analisis data yang diuraikan, secara deskriptif dengan manfaat bantuan komputerisasi program SPSS, setelah melakukan analisis deskriptif tersebut maka pemecahan 
masalah matematik siswa pada materi Sistem Persamaan Linier Dua Variabel (SPLDV) menujukkan bahwa. dari 33 sampel penelitian yang terdiri dari 15 perempuan dan 18 laki-laki yang diselidiki ternyata memiliki skor rata-rata hasil yang diperoleh dalam menyelesaikan soal-soal materi sistem persamaan linier dua variabel siswa kelas VIII SMP Negeri Polewali Mandar adalah 78,27 dengan standar deviasi 80,36 dan variansi sebesar 70,00 dimana skor terendah yang didapat yaitu 54, skor teringgi 90,00 dari skor ideal 100.

Dengan demikaian hasil dari evaluasi yang dilakukan menujukkan bahwa dari 26 siswa atau $79 \%$ mendapat nilai 75 ke atas. Hal ini berarti bahwa deskriptif kemampuan pemecahan masalah matematika siswa kelas VIII SMP Negeri Polewali Mandar pada materi sistem persamaan linier dua variabel (SPLDV) dalam menyelesaikan soal-soal metematika berada pada kategori sedang.

\section{Kesimpulan}

Berdasarkan hasil analisis data dan pembahasan hasil penelitian yang telah diuraikan pada bab sebelumnya dapat di tarik kesimpulan bahwa: Deskripsi kemampuan pemecahan masalah matematika siswa kelas VIII SMP Negeri Polewali Mandar pada materi sistem persamaan linier dua variabel (SPLDV) dalam menyelesaikan soal-soal metematika berada pada kategori sedang. Untuk skor ratarata yang diperoleh adalah 78,27 dari skor maksimum 90 dengan standar deviasi 8,36 dan variansi sebesar 70,01.

\section{Daftar Pustaka}

Arikunto, S. 2010. Prosedur Penelitian Suatu Pendekatan Praktik. Jakarta: Rineka Cipta.

Depdiknas. 2003. Pedoman Khusus Pengembangan Sistem Penilaian Berbasis Kompotensi SMP. Jakarta : Depdiknas.

Depdiknas. 2003. Undang-undang Republik Indonesia Nomor 20 Tahun 2003 Tentang Sistem Pendidikan Nasional. Bandung: Fokusmedia.

Effendi, Zakaria. (2001). Trend Pengajaran Dan Pembelajaran Matematika. Kuala Lumpur: Utusan Publications \& Distributors Sdn. Bhd.

Herman Hudojo, Pengembangan Kurikulum dan Pembelajaran Matematika. Malang, Universitas Negeri malang, 2005.

Ikram. 2012. Desain Tugas untuk Mengidentifikasi Kemampuan Berfikir Kreatif Siswa dalam Matematika. Tesis diterbitkan. Universitas Negeri Makassar.

Leung, Shukkwan S. (1997). On The Role of Creative Thingking in Problem Possing. Htt//www.fiz.katlruhe.de/fiz/publicatians/zdm ZDM Volum 29 ( June 1997) Number 3. Electronik Edition ISSN 1615-679X.

Mulyono Abdurrahman, Pendidikan Bagi Anak Berkesulitan Belajar, (Jakarta: Rineka Cipta, 2003).

Nurkancana, Wayan. 1986. Evaluasi pendidikan Cetakan ke-IV. Surabaya: Usaha Nasional.

Syah, M. 2010. Psikologi Belajar. Jakarta: PT Raja Grafindo Persada. 